\title{
Analysis of SCE on VHS Mathematics Learning
}

\author{
Moh. Mahfud Effendi \\ University of Muhammadiyah Malang, Indonesia \\ effendimahfud4@gmail.com
}

\begin{abstract}
The Strengthening of Character Education is not a new course or curriculum but rather a strengthening of the character values in the learning process. If that purpose is to be achieved, than the character development of every lesson should refer to SCE program. The fundamental problems on Vocational High School mathematics learning is overloaded and overlappedin teaching materials as it has less focus on the important material and not integrated. The question is how to implement SCE on VHS math learning. Therefore, it is necessary to analyze the learning documents of mathematics and interview the teachers of VHS in Malang, Batu, and Bojonegoro. Based on the analysis, the strengthening of the characters values on learning mathematics can be done in the form of individual behavior competence and mathematics learning competence. The strengthening of these character values is not yet optimal, as it has not been explored explicitly and elaborately in basic competence, indicators, objectives, material development/SW, methods, and assessment. Therefore, the strengthening of these character values is not yet relevant.
\end{abstract}

Keywords:VHS, learning math, and character strengthening

\section{INTRODUCTION}

VHS (Vocational High School) mathematical material must be developed and taught according to the needs of its Skill Program [1], [2]. Therefore, the objective of VHS mathematics learning must support student's mastery of the standardized outcomes required by nationally or business and industry or professional association [3], [4], [5].Since the national examination applies in VHS, the orientation of mathematics learning becomes very complex. The complexity leads to overloading and overlapping of teaching materials, so teachers have less focus on important materials, and mathematics learning is not integrated with the purpose of the skill program [6], [1], [7], [8], [9]. On the same conditions, mathematics learning in VHS should also implement The Strengthening of Character Education (SCE) [10], [11], [12]. Therefore, the implementation of this regulation will add a new problem in the development of learning and curriculum of mathematics in VHS.

SCE is not a new course or curriculum but rather a strengthening of the character values in the learning process. If that purpose is to be achieved, the character development of every lesson should refer to SCE program. SCE implementation in learning is grouped into three parts: integration in learning, optimization of character values, and classroom management [10], [11]. The strengthening of these characters values can be in the form of competence, such as the competence of individual behavior or learning competence. In order to implement in the classroom, SCE is integrated in mathematics learning but it does not reduce the function and role of math lessons. This learning not only improves the learning outcomes of mathematics, and the objectives of the skills program, but also reinforces the character values as expected in SCE program.

Many factors influence the successful implementation of SCE in classroom learning, especially the factor of teachers' ability in designing and implementing learning [1].Based on these problems, the purpose of this study is to analyze the relevance of SCE in the design of VHS mathematics learning. Basically, SCE in learning is an optimization of character values and described explicitly in CC (Core Competence), BC (Basic Competence), indicators, objectives and learning, material development, student worksheet (SW), methods, and assessment instruments [13], [12]. Therefore, the development of character values in VHS mathematics learning cannot be separated from those standards [1], [4], [14]. These character values must be relevant to the needs of the skill program and become integrative binders of the character competencies of each subject.

\section{METHOD}

This research is a document study, so the data collection techniques are document analysis techniques [15], [16], [2], [25], [27]. The analyzed documents are 37 Mathematics Learning Plans (MLP) for grade 10 and grade 11, this MLP belongs to SMK in MGMP Malang associations, SMK Bina Mandiri Malang, SMK EL Malang, SMKN 2 Batu, and SMKN Temayang Bojonegoro. For the validity of the data, it also uses data triangulation i.e. interview [16], [2], [17], [18]. This analysis focused on the character values in the MLP, and the relevance of both external and internal. The analysis of external relevance is a conformity analysis of SCE in mathematics learning with SCE in skill programs [13], [19], [20]. While the internal relevance analysis is the consistency or suitability analysis of character values in the $\mathrm{CC}$, with $\mathrm{BC}$, indicators, materials, $\mathrm{CW}$, methods, and assessment [13], [19], [20].

Analysis of external and internal relevance using Likert Scale with four options, namely: very unsuitable, unsuitable, suitable, and very suitable. The document and interview data were analyzed qualitatively to describe the 
relevance level. The process of analysis is that the data obtained are transformed to quantitative data by weighting successively: $1,2,3$, and 4 [11]. Once transformed then the rating scale by using the percentage was determine [2], [11]. To find the relevance level, the rating scale is classified into four categories; very irrelevant, irrelevant, relevant, and very relevant.

\section{RESULT}

Basically, SCE implements thePancasila character values in learning at school. There are 18 characters that are strengthened in learning: religious, honest, tolerant, discipline, hard work, creative, independent, democratic, curious, spirit of nationality, love of the homeland, appreciative to achievement, communicative, love peace, care about the environment, social care, and responsible [21]. These character values are also present in CC [22], so development in $\mathrm{BC}$, indicators, objectives, materials, methods, and assessments should be based on CC.

Not all characters above are written in MLP. Disciplines, responsible, tolerant, and honest are the four character values that exist in the MLP. While that does not exist is the spirit of nationality, love the homeland, and literacy. In fact, the 18 character values are not written explicitly in syntax, material, and SW.

External Relevance

External relevance can be interpreted that there is suitability between the values of characters on learning mathematics with the character values of the program of expertise. That is, SCE development on mathematics lessons should refer to and integrate with SCE of programming skills [6], [23], [1], [7]. Therefore, SCE of the skill program becomesthe binding of SCE to other lessons. VHS mathematics learning should use a problem solving approach [13], [4]. This approach helps students to be able to adapt to science and technology changes through critical, creative, rational, independent, hard work, and meticulous thinking, and can use mathematical thinking in learning other sciences and their other related works [3], [4].

Of the analyzed 37 MLPs, no one wrote a skill program, or MLP was used equally by all skill programs (Table 1). Thus, SCE mathematics between one skill program and the other is the same too (including the very irrelevant categories). This is contrary to the principle of integration, in which the objectives of VHS mathematics learning must support and sustain the objectives of skill programs [6], [7], [9]. It can be concluded that SCE of mathematics at VHS is not in accordance with the principle of external relevance.

Internal Relevance

If a curriculum does not meet the principle of external relevance, then automatically, the curriculum does not meet the principle of relevance, because external relevance is an absolute requirement. In addition, if analyzed on the basis of the principle of internal relevance, i.e.there is no suitability between $\mathrm{CC}, \mathrm{BC}$, indicator, objective, material, SW, syntax, method, and evaluation.
In general, SCE of math at VHS does not meet the principle of internal relevance, because it belongs to very irrelevant categories $(24.1 \%)$. Of the 7 analyzed aspects of relevance, only $\mathrm{BC}$ alone meets the relevance $(50 \%)$, but other aspects are irrelevant. In fact, SCE is not written on indicators, development of teaching materials, and SW. The low levelof internal relevance is due to the fact that teachers: 1) are inconsistent in writing down and describing the character values from $\mathrm{BC}$ to evaluation, 2) have not understood that SCE can be developed and strengthened in mathematics learning, they only know that SCE (in CC- 1 and CC-2) is the responsibility of the lesson of Religion and Moral Education.

\section{DISCUSSION}

Presidential Regulation No. 87, 2017 states that SCE implementation needs to be integrated in the activities: intra-curricular, co-curricular, and extra-curricular. The implementation of SCE in intra-curricular activities is the strengthening of character values on the development of learning materials and methods according to the curriculum [21]. The effectiveness of this implementation depends on how the organization of the curriculum is. Related to that, the SCE of all lessons including mathematics must be supported, suitable, and integrated with SCE of the skill program. Therefore, orientation of the SCE of mathematics learning should support its SCE of the skill program. This can be achieved if the character values in the $\mathrm{BC}$, the indicators, the methods, the teaching materials, and the evaluations are developed consistently, relevantly and integrated with SCE of the skill program [13], [19], [20].

Vocational education (VHS) and moral education are two important issues in curriculum development [24], [23], [25]. Lu Hong expresses the importance of reform in vocational education [26]. Reforms can be interpreted as the development of mathematics curriculum not only covering the mastery of teaching materials but also the reinforcement of moral or character values [21]. Therefore, the development of methods and evaluation of learning outcomes should be able to explore and elaborate mathematical concepts and character values to solve problems faced by the skills program. The reform of mathematics curriculum should focus on what is important and required by its skill program [1], [27]. Redesigning the curriculum is the best way to continually reform the VHS curriculum. Related to that, LIU Deen asserts that the development of VHS curriculum should have four features: job-oriented objectives, applied technology based curriculum content, work activity centered curriculum organization, and curriculum implementation through teaching that is integrated with operation [28]. These four features should be the basis for development SCE in the VHS mathematics curriculum, in order to meet the principles of relevance both externally and internally.

SCE implementation in mathematics learning will be effective if implemented in the form of integrated learning. Integrated learning is a meaningful learning that 
is very effective for achieving the purpose of learning. The SCE objectives of each subject at VHS should be directed to the effectiveness of SCE's achievement of the skill programs. So far, the orientation of VHS mathematics learning is separated between cognitive, affective, and psychomotor, including lessons of the skill program [6]. If all are integrated, it will have a positive impact on achieving SCE's goals for each skill program [1], [29].

\section{CONCLUSION}

The purpose of SCE is to strengthen the values of student character in school. Therefore, character values must be one of the learning goals of all subjects including mathematics. SCE in VHS mathematics lesson should be developed in an integrated manner through the relevance principle of external and internal correlations. The low morale of students is also caused by to the low relevance of SCE development on the curriculum. Based on the results of the analysis, it can be concluded that: 1) SCE has not been the focus of learning; 2) SCE in math lesson is not integrated with SCE of skill program, meaning it does not meet the principle of external relevance; and 3) the lack of consistency or coherence between the development of character values in BC, indicators, learning objectives, teaching materials, methods, and evaluation of learning VHS mathematics does not meet the principle of internal relevance. Thus it can be concluded that the strengthening of SCE in VHS mathematics learning does not meet the principle of relevance.

\section{REFERENCES}

[1]. Effendi, Moh Mahfud. Pengembangan Kurikulum Matematika sebagai Mata Pelajaran Adaptif pada Program Keahlian Tata Busana SMKN 3 Probolinggo. Jurnal Penelitian Pendidikan 1412565X Edisi khusus Februari 2013 hal 43-60. 2013.

[2]. McMillan, James H. Educational Research: Fundamentals for The Consumer, $5^{\text {th }}$ Edition USA: Person Education, Inc.2008.

[3]. HenkvdK,. Mathematics for Technical Vocational Education. Research Intersts and Universities. http://www.academica.edu. 2010.

[4]. Lisberg L dan Lulea T,.To Look for Mathematics Teaching and Learning in Vocational Education. www.mail.liu.se/SMDF/madif5/Lindberg. 2013.

[5]. Pusdiknakes. Kurikulum SMK.Tersedia: http://www.pusdiknakes.or.id /data/kurikulum/ smk.doc. www.infokursus.net.pdf. 2010.

[6]. Beane, James A. Curriculum Integration; Designing the core of democratic Education. New York and London: Teachers College Press.1977.

[7]. Fang, LI Ju, and Zheng, ZHOU Jian. The construction and implementation of work-integrated learning "Three Policy" model in the vocational college of mapping class: Journal Science of Surveying and Mapping; 2010-05. 2010.
[8]. Ferestehet.al., Mathematics Requirements for Vocational and Technical Education. www.tree.utm.mymp. 2012.

[9]. Fogarty. How to Integrate The Curricula: The Mindful School. Illinois: Skylight Publishing, Inc.1991.

[10]. Budhiman, Arie. Gerakan Penguatan Pendidikan Karakter. Kemendikbud RI. 2017.

[11]. Oppenheim, A.N. Questionare Design and Attitude Measurement. London: Heinemann.1982.

[12]. Tim PPK. Modul Pelatihan PPK Bagi Guru. Pusat Analisis dan Sinkronisasi Kebijakan, Kemendikbud. Jakarta. 2017.

[13]. Effendi, Moh. Mahfud. Analysis of Relevance of VHS Mathematics Curriculum Development: Journal Advances in Social Science, Education and Humanities Research. ISBN: 978-94-6252-4941. DOI:10.2991/incomed-17.2018.1.2018.

[14]. Udelhofen, Susan. Keys to Curriculum Mapping: Strategies and Tools to Make It Work. California: Corwin Press.2005.

[15]. Borg WR \& Gall M.P. Educational Research, An Introduction $7^{\text {th }}$ Edition. Pearson Education, Inc.2003.

[16]. Gay,L.R, et.al,. Educational Research: Competencies for Analysis and Applications. New Jersey: Pearson Prentice Hall.2006.

[17]. Sugiyono. Metode Penelitian Kuantitatif, Kualitatif, dan R\&D. Bandung; Alfabeta.2008.

[18]. Sukmadinata. Metode Penelitian Pendidikan. Bandung: Remaja Rosdakarya. 2010.

[19]. Sanjaya, W. Kurikulum dan Pembelajaran; Teoridan Praktek Pengembangan KTSP. Jakarta: Kencana Prenada Media Group.2008.

[20]. Sukmadinata Pengembangan Kurikulum: Teori dan Praktek. Bandung: Remaja Rosdakarya. 2008.

[21]. Peraturan Presiden Republik Indonesia Nomor 87 Tahun 2017 Tentang Penguatan Pendidikan Karakter

[22]. PermendiknasNomor 22 Tahun 2006 Tanggal 23 Mei 2006 TentangStandar Isi, SKKD, StrukturKurikulum SMK/MAK.

[23]. Dayuan, Jiang. Thoughts on Fundamental Problems of Vocational Education Pedagogy: Journal Vocational and Technical Education; 2006-04.2006.

[24]. Bowers, Helen. Curriculum Design in Vocational Education. Fully refereed paper for the Australian Association for Research in Education-2006 Conference 26-30 November 2006, Adelaide. 2006.

[25]. McNeil. Contemporary Curriculum in Thought \& Action. USA: John Wiley \& Sons. 2006.

[26]. Lu Hong. Thought and Practice on Curriculum Reform in Higher Vocational Colleges: Journal of Anhui Vocational \& Technical College; 2009-01, [Cate Gory Index]: F830-4;F712.3. 2009.

[27]. Karseth, Berit. Curriculum Restructuring In Higher Education After The Bologna Process: A New Pedagogic Regime.This article is a revised version for this monograph of a paper presented at The Third Conference on Knowledge and Politics at the 
University of Bergen, May 18-20th, 2005. Journal: Revista Española de Educación Comparada, 12 (2006), 255-284. 2006.

[28]. Deen, LIU. Characteristics of Curriculum in Higher Vocational Education: Journal Vocational and Technical Education; 2001-16. 2001.

[29]. Gloria Lo, et.al. When Academia Meets Industry: Effective ESP Curriculum Development for
Vocational High School Students Delivering Profesional Business Presentations. English as a Global Language Education (EaGLE) Journal: Vol. 1 No. 2; pag. 31-62.2015.

[30]. Yimin, Wang. Exploitation and Practice of Theorypractice Integrated Professional Courses: Journal Vocational and Technical Education; 2006-04. 2006. 